\title{
Advances in treating psoriasis
}

\section{Katharina Belge, Jürgen Brück and Kamran Ghoreschi*}

\author{
Address: Department of Dermatology, University Medical Center, Eberhard Karls University of Tübingen, Liebermeisterstr. 25, 72076 Tübingen, \\ Germany \\ *Corresponding author: Kamran Ghoreschi (kamran.ghoreschi@med.uni-tuebingen.de) \\ FI000Prime Reports 2014, 6:4 (doi:10.12703/P6-4) \\ This is an open-access article distributed under the terms of the Creative Commons Attribution-Non Commercial License \\ (http://creativecommons.org/licenses/by-nc/3.0/legalcode), which permits unrestricted use, distribution, and reproduction in any medium, \\ provided the original work is properly cited. You may not use this work for commercial purposes. \\ The electronic version of this article is the complete one and can be found at: http://fl 000.com/prime/reports/m/6/4
}

\begin{abstract}
Psoriasis is a T helper (Th) I7/Thl-mediated autoimmune disease affecting the skin and joints. So far, distinct traditional oral compounds and modern biologics have been approved in most countries for the treatment of patients with moderate to severe psoriasis or psoriatic arthritis. Yet, the anti-psoriatic therapeutic spectrum is to be extended by a number of novel targeted therapies including biologics and modern oral compounds. The next set of anti-psoriatic biologics targets mainly Th I7-associated cytokines such as IL-17 or IL-23. In contrast, modern oral anti-psoriatics, such as dimethyl fumarate (DMF), apremilast or Janus kinase (JAK) inhibitors interfere with intracellular proteins and affect signaling pathways. Here we summarize the current systemic therapies for psoriasis and their immunological mechanism. The recent advances in psoriasis therapy will help treat our patients efficiently and complete our understanding of disease pathogenesis.
\end{abstract}

\section{Chronic inflammation of skin and joints}

Psoriasis is a chronic inflammatory immune-mediated disease of skin and joints affecting around $0.5-1 \%$ of children and $2-3 \%$ of adults [1]. Typically, the patients develop erythematous scaly papules and plaques. Up to 20 or $30 \%$ of patients with psoriasis develop psoriatic joint involvement, which may result in severe joint destruction and (in rare cases) mutilating arthritis. Both psoriasis of the skin and psoriatic arthritis are frequently accompanied by impairment of quality of life. The burden of disease is complicated by several comorbidities, such as cardiovascular and metabolic diseases.

Today, we are fortunate to have a broad spectrum of antipsoriatic agents, including small molecules and biologics, either available or in development. The basis of modern anti-psoriatic therapeutics is our understanding of psoriasis pathogenesis. Experimental research and clinical observations have allowed us to identify important cellular and molecular mediators in psoriasis. Innate and adaptive immune cells contribute to psoriasis pathogenesis. Currently, psoriasis is considered an inflammatory autoimmune disease dominated by interleukin (IL)-17-producing
$\mathrm{CD} 4^{+}$Th cells (Th17). Infiltrating mast cells and neutrophils are further cellular sources of IL-17 in psoriasis. Activated innate immune cells like dendritic cells (DC) (but also local tissue cells like keratinocytes) provide further factors promoting Th17 responses. Th17 cells and their associated cytokines have multiple effects on resident tissue cells within the skin or joints [2]. Moreover, Th17 cells interact with other immune cells and can attract neutrophils to the site of inflammation. While the inflammation causing erythematous scaly plaques of the skin can be clinically cleared without visible scarring, perpetuated inflammation of the joints can result in cartilage and bone destruction, followed by severe mutilation. Thus, our therapeutic decisions must be preceded by careful history and diagnostic procedures. Here we want to summarize the established therapeutic options in psoriasis and the new advances in modern psoriasis management with systemic therapeutics based on the disease immunopathogenesis.

\section{Psoriasis - a ThI7 disease}

The dermal infiltrate in psoriasis typically contains various immune cells. A pronounced proliferation of keratinocytes and dermal vascular endothelial cells 
follows the inflammatory response. It has been suggested that disease manifestation is connected to genetic susceptibility and environmental triggering factors. Despite the association between psoriasis and certain human leukocyte antigens (HLAs), such as HLA-Cw6, a number of gene polymorphisms have been linked to psoriasis. Importantly, some of these genes encode Th17-associated factors such as IL23A, IL23R, STAT3, RUNX3 and TYK2 [3,4]. In addition, environmental conditions, infections or certain drugs can facilitate disease manifestation. It is speculated that innate signals first activate antigen-presenting cells within the skin, followed by a $\mathrm{CD} 4^{+} \mathrm{T}$ cell response. For a long period of time, psoriatic skin was thought to be primarily dominated by type 1 responses, as characterized by the presence of IL-12-expressing DC and Th1 cells, which secrete interferon (IFN)- $\gamma$, tumor necrosis factor (TNF) and IL-2 (Figure 1) [5-7]. More recently, a cytokine sharing the p40 unit with IL-12 and IL-23 was reported to be highly expressed in psoriatic skin [8]. This cytokine is crucial for the generation of Th17 cells with a pathogenic phenotype $[9,10]$. IL-23 promotes the expression of IL17A, IL-17F and IL-22 by Th17 cells (Figure 1) [11,12]. The Th17 phenotype, its associated transcription factor

Figure I. Cytokines, immune cells and signaling proteins implicated in psoriasis pathogenesis and therapeutic targeting by small molecules and biologics

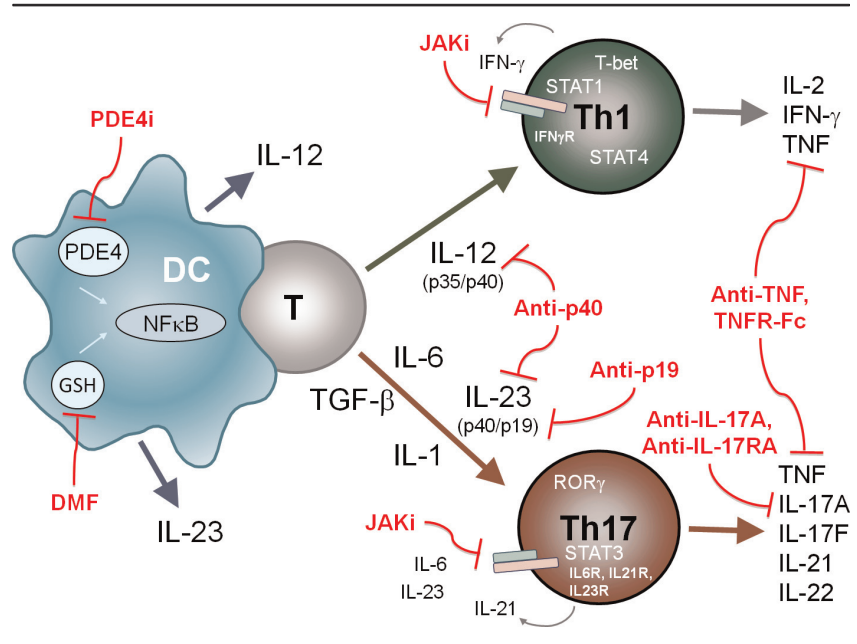

Dendritic cells (DCs) activate naïve T cells to differentiate into IFN- $\gamma^{+} \mathrm{T}$-bet ${ }^{+}$ ThI cells in the presence of IL- 12 or into IL- $17^{+} \mathrm{ROR}^{+}{ }^{+} \mathrm{Th} / 7$ cells in the presence of IL-6, IL-I, TGF- $\beta$ and IL-23. While STAT4 (activated by IL-I2) and STATI (activated by IFN- $\gamma^{+}$) are important for ThI differentiation, STAT3 (activated by IL-6, IL-2I and IL-23) is required for Th 17 cell differentiation. Dimethyl fumarate (DMF) and apremilast (PDE4i) modulate cytokine expression in activated DCs. JAK inhibitors (Jaki) prevent cytokine receptor signaling. Antibodies or fusion proteins (TNFR-Fc) neutralize the indicated cytokines important for Th cell differentiation or effector cytokines implicated in psoriasis pathogenesis. $\mathrm{GSH}$, glutathione; NFkB, nuclear factor kappa B; PDE4, phosphodiesterase type 4.
ROR $\gamma$ and chemokine CCL20 are readily detectable in psoriatic skin [13]. Similarly, Th1 cells, Th17 cells and associated factors have been found in the joints of patients with psoriatic arthritis [14]. In patients suffering from moderate to severe psoriasis a number of systemic treatments are approved to control the chronic inflammation (Table 1).

\section{Traditional oral therapies}

Most clinicians initiate methotrexate as first-line systemic therapy for patients with psoriasis or psoriatic arthritis. Others use cyclosporine, which induces general immunosuppression by preventing $\mathrm{T}$ cell activation and cytokine expression. Both compounds are effective in psoriasis and psoriatic arthritis [15]. However, their longterm use is complicated by several toxicities. Patients suffering from pustular psoriasis can also benefit from oral retinoids, while patients with psoriasis vulgaris respond better to oral retinoids when receiving additional phototherapy [16]. In some countries fumaric acid esters (FAEs) are used for treating psoriasis. FAEs seem to improve psoriasis by acting on the immune response and inhibiting the production of pro-inflammatory cytokines like IL-12 and IL-23 $[17,18]$. FAE therapy is regarded as an anti-psoriatic therapy with limited toxicity. Because rare reports on progressive multifocal leukoencephalopathy (PML) exist in patients with severe lymphopenia under FAE treatment, severe and long-lasting lymphopenia should be avoided when patients are treated with this drug [19].

\section{Established anti-psoriatic biologics}

For many years, classical oral immunosuppressants and antiproliferative drugs were recognized as the only effective therapeutics for improving psoriasis. In contrast, antipsoriatic biologics target one single receptor or cytokine, which may affect multiple components of the immune system. The first biologics approved for psoriasis (such as efalizumab and alefacept) were primarily directed against receptors involved in $\mathrm{T}$ cell transmigration or activation. Both of these drugs have since been discontinued. More recently, biologics were generated to neutralize cytokines such as TNF, a critical mediator released by inflammatory Th1 and Th17 cells, but also by many other cells. TNF antagonists revolutionized the therapy of psoriasis and psoriatic arthritis with impressive response rates. The majority of patients treated with anti-TNF antibodies such as adalimumab or infliximab show at least a $75 \%$ improvement of the clinical psoriasis area and severity index (PASI-75) score [20,21]. Likewise, 34 to $49 \%$ of patients receiving the TNF receptor fusion protein etanercept achieve a PASI-75 response at week 12 after treatment initiation [22]. Golimumab and certolizumab pegol have extended the spectrum of this group of anti-TNF drugs 
Table I. Anti-psoriatic oral compounds and biologics

\begin{tabular}{|c|c|c|}
\hline Category & Therapeutic & Target, mode of action \\
\hline \multirow[t]{4}{*}{ Traditional oral compounds } & Methotrexate & Folic acid antagonist; inhibits $\mathrm{T}$ cell activation \\
\hline & Cyclosporine & Inhibits $\mathrm{T}$ cell activation and cytokine secretion \\
\hline & Retinoids & Vitamin A analogs inhibiting epidermal proliferation and differentitation \\
\hline & Fumaric acid esters & GSH conjugation, changes in cytokine production \\
\hline \multirow[t]{4}{*}{ Established biologics } & Infliximab & Antibody neutralizing TNF \\
\hline & Etanercept & TNFR fusion protein \\
\hline & Adalimumab & Antibody neutralizing TNF \\
\hline & Ustekinumab & Antibody neutralizing IL-I2/IL-23p40 \\
\hline \multirow[t]{3}{*}{$\begin{array}{l}\text { Modern oral compounds } \\
\text { (phase } 3 \text { development) }\end{array}$} & Dimethyl fumarate & $\begin{array}{l}\text { GSH conjugation, Nrf2 activation, inhibition of IL-I } 2 \text { and IL-23, induction of IL-I0 } \\
\text { and Th2 }\end{array}$ \\
\hline & Apremilast & $\begin{array}{l}\text { PDE4 inhibitor, increase of cAMP, inhibition of IL-I2, IL-23, TNF and IFN- } \gamma \text {, } \\
\text { inhibition of IL- I0 }\end{array}$ \\
\hline & Tofacitinib & JAK inhibitor silencing cytokine receptor signaling, inhibiting Th I and ThI7 responses \\
\hline \multirow{4}{*}{$\begin{array}{l}\text { New biologics } \\
\text { (phase } 3 \text { development) }\end{array}$} & Brodalumab & Antibody binding IL-I7 receptor A(IL-I7RA) \\
\hline & Ixekizumab & Antibody neutralizing IL-I7A \\
\hline & Secukinumab & Antibody neutralizing IL-I7A \\
\hline & MK-3222 & Antibody neutralizing IL-23p I9 \\
\hline
\end{tabular}

Approved or in phase 3 development according to http://clinicaltrials.gov/

GSH, glutathione; PDE4, phosphodiesterase type 4; TNF, tumor necrosis factor.

and have been approved for psoriatic arthritis [23,24]. Like oral immunosuppressants, TNF antagonists are linked to certain safety concerns. However, serious infections seem to be more common when using TNF antagonists for rheumatoid arthritis or Crohn's disease than for psoriasis or psoriatic arthritis [25]. Furthermore, patients with psoriasis treated with TNF blockers seem to have an increased risk of non-melanoma skin cancer $[26,27]$.

Ustekinumab is a biologic approved for psoriasis, targeting cytokines other than TNF. This monoclonal antibody is directed against the p40 subunit shared by IL-23 and IL-12. In this manner, ustekinumab can inhibit the development of Th17 and Th1 responses. More than $65 \%$ of patients receiving anti-p40 therapy with ustekinumab show a PASI-75 response at week 12 [28]. Serious infections, malignancies and adverse cardiovascular events have been observed under therapy with neutralizing p40 antibodies [29], but so far the data do not suggest increased rates of these adverse events with ustekinumab [30]. The efficacy of neutralizing TNF or IL-12/IL-23p40 in psoriasis, and their distinct intracellular signaling pathways, suggests that various molecular mechanisms participate in the immunopathogenesis of psoriasis.

\section{Advances in anti-psoriatic biologics}

While the pathogenic role of TNF in psoriatic arthritis and rheumatoid arthritis is well established, the exact effects of IL-12 and IL-23 in inflammatory joint destruction are less well understood. More recently, a phase 3 trial demonstrated efficacy and safety of ustekinumab in patients with psoriatic arthritis. Neutralizing p40 significantly improved psoriatic arthritis including associated dactylitis and enthesitis [31]. Interestingly, there is no published data indicating that ustekinumab may also be effective in rheumatoid arthritis. A cytokine closely associated with IL-23 is IL-17, which is produced by infiltrating neutrophils, mast cells and T cells in psoriatic skin [32]. Currently, there are three different IL-17 antagonists under clinical evaluation for psoriasis (Table 1). The monoclonal antibodies ixekizumab and secukinumab both target IL-17A, while brodalumab blocks the IL-17 receptor IL-17RA. The efficacy data on IL-17 neutralization for psoriasis is quite impressive. Phase 2 trials demonstrated PASI-75 responses in more than $70 \%$ of patients treated with anti-IL-17A or anti-IL-17RA antibodies and they all entered phase 3 [33-35]. Their safety profile is preliminary.

As targeting IL-17 in psoriasis of the skin produced such a remarkable response in early trials, it posed the question of whether this approach would also be successful in autoimmune arthritis. There is some indication that this might be the case in experimental arthritis where IL-23, IL-17 and IL-22 have been linked to joint inflammation $[36,37]$. However, recently published phase 2 data show that anti-IL-17 strategies seem to only have a modest impact on the disease course in rheumatoid arthritis, although some clinical benefit was observed in psoriatic arthritis [38,39]. The upcoming efficacy data on neutralizing p40 (IL-12 and IL-23) or IL-17 in psoriatic arthritis or rheumatoid arthritis will help to clarify whether Th17 responses are more prominent in the pathogenesis of psoriatic arthritis or rheumatoid arthritis. Thus, we learn a great deal about common pathways and distinct details in the pathogenesis of psoriasis, psoriatic arthritis and rheumatoid arthritis by using biologics that selectively neutralize the effects of one or two mediators. 


\section{Novel oral anti-psoriatics}

Modern biologics have helped to establish new targeted therapies with dramatic efficacy in psoriasis, even in patients who failed to respond to traditional oral therapies. Yet, more recently there has been a trend to introduce additional oral anti-psoriatic compounds that specifically interfere with intracellular metabolic processes, with key proteins or with signaling pathways relevant to psoriasis (Table 1). One of these approaches is to use one single compound derived from an anti-psoriatic formulation containing FAE. DMF is considered to be the important active compound among other FAEs and this compound has been tested in psoriasis and other inflammatory diseases $[18,40,41]$. Phase 3 trials have shown the efficacy of DMF in multiple sclerosis, and DMF has been approved as oral treatment in multiple sclerosis in the US $[42,43]$. DMF seems to interact with nuclear factor kappa B (NFkB) activation and inhibits the expression of IL-12 and IL-23 by macrophages and DCs (Figure 1) [18,44,45]. Notably, DMF is the first modern therapeutic that is clinically effective in psoriasis and multiple sclerosis, unlike established biologics $[18,42,43]$. Blocking TNF or neutralizing p40 with biologics were disappointing strategies in multiple sclerosis $[46,47]$. Although effective in psoriasis of the skin, patients with established arthritis do not seem to benefit from FAE therapy. The adverse event spectrum of DMF seems to be similar to that of the established formulation of FAE. A second compound influencing intracellular processes is the phosphodiesterase type 4 (PDE4) inhibitor apremilast. It has been reported that this compound decreases the release of pro-inflammatory cytokines (such as IL-12, IL-23 and TNF) and induces anti-inflammatory cytokines like IL-10 (Figure 1) [48]. Recent phase 2 data indicate that apremilast treatment induces significant improvement in psoriasis and psoriatic arthritis as determined by PASI-75 responses or ACR20 responses $[49,50]$. So far, common and relatively general side effects have been reported.

A number of oral compounds under investigation for clinical efficacy and safety in psoriasis, psoriatic arthritis and rheumatoid arthritis are kinase inhibitors, interfering with cytokine receptor signaling. Major efforts have been made to generate small molecules that inhibit the signal transduction of type I and type II cytokine receptors (receptors for IL-2, IL-6, IL-22, IL-23, IFN- $\gamma$ and others Figure 1) [51,52]. The signal transmission of these receptors requires the association with kinases from the JAK family. JAK inhibitors can interfere with cytokine signaling and thus suppress immune cell activation and inflammation [53,54]. One of the clinically most advanced JAK inhibitors, tofacitinib, has been approved for the treatment of rheumatoid arthritis in the US and in some countries in Europe, Asia and South America. However, this drug has not yet received marketing authorization by the European Medicines Agency. Oral JAK inhibitors with different degrees of selectivity for JAK family members are now being tested for psoriasis and psoriatic arthritis. Moreover, topical formulations are being tested for psoriasis of the skin [55]. First results show significant response rates according to PASI-75 or ACR20 responses [56-59]. The safety profile of JAK inhibition seems to be acceptable but is still too preliminary.

\section{Future concepts and conclusion}

The concept of general and non-specific immunosuppression as a first-line therapy for psoriasis should be revised in the light of modalities targeting single cytokines or intracellular key proteins implicated in psoriasis pathogenesis. These new modalities have helped us to improve our understanding of disease pathogenesis and of common pathways in psoriasis, psoriatic arthritis or rheumatoid arthritis. A number of new therapies are approaching clinical practice in dermatology. Ustekinumab was the first anti-cytokine biologic used exclusively by dermatologists and is now being established for psoriatic arthritis [31]. Other inflammatory conditions may also benefit from neutralizing p40 [60]. We are also looking forward to learning about the safety and efficacy of directly neutralizing IL-23, without affecting IL-12 and Th1 responses, which are necessary to control tumors and viral infections [61]. Targeting IL-23a, the p19 unit forming IL-23 together with p40, is currently under investigation as therapy for patients with psoriasis. This experience will help decipher the importance of IL-23/Th17 and IL-12/ Th1 responses in psoriasis and may destroy an old dogma concerning the relevance of Th1 cells in this disease. Notably, neutralizing IL-17 or blocking IL-17R will most likely be the second biologic approach primarily used in dermatology. The efficacy of antibodies directed against TNF, IL-17 or IL-23 demonstrate clearly that the immune disease psoriasis can be treated by either neutralizing the cytokines secreted by Th17 cells, neutrophils and mast cells or by inhibiting the cytokine-mediated activation of these cell populations. Both therapeutic categories neutralizing Th17 cytokines or preventing Th17 development can be extended by further biologics. One might assume that neutralizing the Th17-associated cytokine IL-22, which primarily affects keratinocyte biology, could be effective for the treatment of psoriasis [62]. Alternatively, one could dampen the inflammation by administrating cytokines, which prevent Th17 and/or Th1 responses [63]. The latter approach has been shown in a proof-of-concept study, where the administration of IL-4 improved psoriasis and induced Th2 responses in a phase 1/2 trial [7].

Moreover, a next generation of oral compounds may enter daily clinical practice in psoriasis. The use of DMF 
in psoriasis has opened a new therapeutic option for patients with multiple sclerosis $[42,43]$. Apremilast, with its favorable safety profile and its efficacy data, will presumably extend the list of oral compounds in psoriasis. Finally, directly targeting cytokine receptor signaling pathways with JAK inhibitors may be a promising approach for systemic or even topical treatment of psoriasis [64]. Thus, we are in the fortunate position where we can offer our patients with psoriasis at least eight different systemic therapies, which are established in many countries. There are at least four upcoming biologics and three oral compounds that will presumably extend our therapeutic spectrum (Table 1). Yet, we have to understand the mechanisms in non-responders, and those with a loss of response, in order to provide them with a life-long protection from psoriasis and psoriatic arthritis. Also, safety issues and the advantage of combination therapies still have to be studied in more detail. The development of further effective and safe anti-psoriatic therapeutics is not yet complete.

\section{Abbreviations}

ACR, American College of Rheumatology; DC, dendritic cell; DMF, dimethyl fumarate; FAE, fumaric acid ester; HLA, human leukocyte antigen; IFN, interferon; IL, Interleukin; JAK, Janus kinase; NFKB, nuclear factor kappa B; PASI, psoriasis area and severity index; PDE4, phosphodiesterase type 4; PML, progressive multifocal leukoencephalopathy; Th, T helper; TNF, tumor necrosis factor.

\section{Disclosures}

Katharina Belge has been an investigator for Abbott, Almirall, Biogen Idec, Celgene, Eli Lilly and Company, Janssen-Cilag, MSD Sharp \& Dohme, Novartis Pharmaceuticals and Pfizer. Kamran Ghoreschi has been a consultant, lecturer or investigator for Abbott, Almirall, Biogen Idec, Celgene, Eli Lilly and Company, Janssen-Cilag, MSD Sharp \& Dohme, Novartis Pharmaceuticals, Pfizer and the Schering-Plough Research Institute. Jürgen Brück and Kamran Ghoreschi received a research grant from Fumapharm AG (now Biogen Idec).

\section{Acknowledgements}

This work was supported by the Bundesministerium für Bildung und Forschung (BMBF) 0315079 and the Deutsche Forschungsgemeinschaft (DFG) Sonderforschungsbereich 685 .

\section{References}

I. Parisi R, Symmons DPM, Griffiths CEM, Ashcroft DM: Global epidemiology of psoriasis: a systematic review of incidence and prevalence. J Invest Dermatol 2013, 133:377-85.

\section{FlOOOPrime}

\section{RECOMMENDED}

2. van den Berg WB, Miossec P: IL-I7 as a future therapeutic target for rheumatoid arthritis. Nat Rev Rheumatol 2009, 5:549-53.
3. Nair RP, Duffin KC, Helms C, Ding J, Stuart PE, Goldgar D, Gudjonsson JE, Li Y, Tejasvi T, Feng B, Ruether A, Schreiber S, Weichenthal M, Gladman D, Rahman P, Schrodi SJ, Prahalad S, Guthery SL, Fischer J, Liao W, Kwok P, Menter A, Lathrop GM, Wise CA, Begovich AB, Voorhees JJ, Elder JT, Krueger GG, Bowcock AM, Abecasis GR: Genome-wide scan reveals association of psoriasis with IL-23 and NF-kappaB pathways. Nat Genet 2009, 4 I: 199-204.

\section{FlOOOPrime \\ RECOMMENDED}

4. Strange A, Capon F, Spencer CCA, Knight J, Weale ME, Allen MH, Barton A, Band G, Bellenguez C, Bergboer JGM, Blackwell JM, Bramon E, Bumpstead SJ, Casas JP, Cork MJ, Corvin A, Deloukas P, Dilthey A, Duncanson A, Edkins S, Estivill X, Fitzgerald O, Freeman C, Giardina E, Gray E, Hofer A, Hüffmeier U, Hunt SE, Irvine AD, Jankowski J, et al.: A genome-wide association study identifies new psoriasis susceptibility loci and an interaction between HLA-C and ERAPI. Nat Genet 2010, 42:985-90.

\section{FlOOOPrime}

RECOMMENDED

5. Yawalkar N, Karlen S, Hunger R, Brand CU, Braathen LR: Expression of interleukin- 12 is increased in psoriatic skin. J Invest Dermatol 1998, III:1053-7.

6. Nestle FO, Turka LA, Nickoloff BJ: Characterization of dermal dendritic cells in psoriasis. Autostimulation of $\mathrm{T}$ lymphocytes and induction of ThI type cytokines. J Clin Invest 1994, 94:202-9.

7. Ghoreschi K, Thomas P, Breit S, Dugas M, Mailhammer R, van Eden W, van $\operatorname{der}$ Zee R, Biedermann T, Prinz J, Mack M, Mrowietz U, Christophers E, Schlöndorff D, Plewig G, Sander CA, Röcken M: Interleukin-4 therapy of psoriasis induces Th2 responses and improves human autoimmune disease. Nat Med 2003, 9:40-6.

\section{FlOOOPrime}

RECOMMENDED

8. Lee E, Trepicchio WL, Oestreicher JL, Pittman D, Wang F, Chamian F, Dhodapkar M, Krueger JG: Increased expression of interleukin 23 pl9 and p40 in lesional skin of patients with psoriasis vulgaris. J Exp Med 2004, 199:125-30.

\section{FlOOOPrime}

RECOMMENDED

9. McGeachy MJ, Chen Y, Tato CM, Laurence A, Joyce-Shaikh B, Blumenschein WM, McClanahan TK, O'Shea JJ, Cua DJ: The interleukin 23 receptor is essential for the terminal differentiation of interleukin 17-producing effector $\mathrm{T}$ helper cells in vivo. Nat Immunol 2009, 10:314-24.

10. Ghoreschi K, Laurence A, Yang X, Hirahara K, O'Shea J]: T helper $\mathbf{I 7}$ cell heterogeneity and pathogenicity in autoimmune disease. Trends Immunol 20I I, 32:395-40I.

II. Aggarwal S, Ghilardi N, Xie M, de Sauvage FJ, Gurney AL: Interleukin-23 promotes a distinct CD4 $\mathrm{T}$ cell activation state characterized by the production of interleukin-I7. J Biol Chem 2003, 278:1910-4.

12. Ghoreschi K, Laurence A, Yang X, Tato CM, McGeachy MJ, Konkel JE, Ramos HL, Wei L, Davidson TS, Bouladoux N, Grainger JR, Chen Q, Kanno Y, Watford WT, Sun H, Eberl G, Shevach EM, Belkaid Y, Cua DJ, Chen W, O'Shea J]: Generation of pathogenic $\mathbf{T}(\mathbf{H}) 17$ cells in the absence of TGF- $\beta$ signalling. Nature 2010, 467: 967-71.

\section{FlOOOPrime RECOMMENDED}

13. Wilson NJ, Boniface K, Chan JR, McKenzie BS, Blumenschein WM, Mattson JD, Basham B, Smith K, Chen T, Morel F, Lecron J, Kastelein RA, Cua DJ, McClanahan TK, Bowman EP, de Waal Malefyt R: Development, cytokine profile and function of human 
interleukin I7-producing helper T cells. Nat Immunol 2007, 8:950-7.

\section{FlOOOPrime RECOMMENDED}

14. Leipe J, Grunke M, Dechant C, Reindl C, Kerzendorf U, Schulze-Koops H, Skapenko A: Role of ThI7 cells in human autoimmune arthritis. Arthritis Rheum 2010, 62:2876-85.

\section{FlOOOPrime RECOMMENDED}

15. Heydendael VMR, Spuls PI, Opmeer BC, Borgie CAJM de, Reitsma JB, Goldschmidt WFM, Bossuyt PMM, Bos JD, de Rie MA: Methotrexate versus cyclosporine in moderate-to-severe chronic plaque psoriasis. N Engl J Med 2003, 349:658-65.

16. Sbidian E, Maza A, Montaudié H, Gallini A, Aractingi S, Aubin F, Cribier B, Joly P, Jullien D, Le Maître M, Misery L, Richard M, Paul C, Ortonne J, Bachelez $\mathrm{H}$ : Efficacy and safety of oral retinoids in different psoriasis subtypes: a systematic literature review. J Eur Acad Dermatol Venereol 20I I, 25(Suppl 2):28-33.

\section{FIOOOPrime}

17. Litjens NHR, Rademaker M, Ravensbergen B, Rea D, van der Plas MJA, Thio B, Walding A, van Dissel JT, Nibbering PH: Monomethylfumarate affects polarization of monocyte-derived dendritic cells resulting in down-regulated ThI lymphocyte responses. Eur J Immunol 2004, 34:565-75.

18. Ghoreschi K, Brück J, Kellerer C, Deng C, Peng H, Rothfuss $O$, Hussain RZ, Gocke AR, Respa A, Glocova I, Valtcheva N, Alexander E, Feil S, Feil R, Schulze-Osthoff K, Rupec RA, Lovett-Racke AE, Dringen R, Racke MK, Röcken M: Fumarates improve psoriasis and multiple sclerosis by inducing type II dendritic cells. J Exp Med 20II, 208:229I-303.

\section{FIOOOPrime}

19. Sweetser MT, Dawson KT, Bozic C: Manufacturer's response to case reports of PML. N Engl J Med 20I3, 368:I659-6I.

\section{FIOOOPrime
RECOMMENDED}

20. Chaudhari U, Romano P, Mulcahy LD, Dooley LT, Baker DG, Gottlieb AB: Efficacy and safety of infliximab monotherapy for plaque-type psoriasis: a randomised trial. Lancet 200I, 357:1842-7.

\section{FlOOOPrime \\ RECOMMENDED}

21. Menter A, Tyring SK, Gordon K, Kimball AB, Leonardi CL, Langley RG, Strober BE, Kaul M, Gu Y, Okun M, Papp K: Adalimumab therapy for moderate to severe psoriasis: A randomized, controlled phase III trial. J Am Acad Dermatol 2008, 58:106-15.

\section{FlOOOPrime}

22. Mease PJ, Goffe BS, Metz J, VanderStoep A, Finck B, Burge DJ: Etanercept in the treatment of psoriatic arthritis and psoriasis: a randomised trial. Lancet 2000, 356:385-90.

\section{FlOOOPrime RECOMMENDED}

23. Kavanaugh A, van der Heijde D, Mclnnes IB, Mease P, Krueger GG, Gladman DD, Gómez-Reino J, Papp K, Baratelle A, Xu W, Mudivarthy S, Mack M, Rahman MU, Xu Z, Zrubek J, Beutler A: Golimumab in psoriatic arthritis: one-year clinical efficacy, radiographic, and safety results from a phase III, randomized, placebo-controlled trial. Arthritis Rheum 2012, 64:2504-17.

\section{FloOOPrime} RECOMMENDED

24. Mease PJ, Fleischmann R, Deodhar AA, Wollenhaupt J, Khraishi M, Kielar D, Woltering F, Stach C, Hoepken B, Arledge T, van der Heijde D: Effect of certolizumab pegol on signs and symptoms in patients with psoriatic arthritis: 24-week results of a Phase 3 double-blind randomised placebo-controlled study (RAPID-PsA). Ann Rheum Dis 20I4, 73:48-55.

\section{FlOOOPrime}

\section{RECOMMENDED}

25. Burmester GR, Panaccione R, Gordon KB, Mcllraith MJ, Lacerda APM: Adalimumab: long-term safety in $23 \mathbf{4 5 8}$ patients from global clinical trials in rheumatoid arthritis, juvenile idiopathic arthritis, ankylosing spondylitis, psoriatic arthritis, psoriasis and Crohn's disease. Ann Rheum Dis 2013, 72:517-24.

26. Dommasch ED, Abuabara K, Shin DB, Nguyen J, Troxel AB, Gelfand JM: The risk of infection and malignancy with tumor necrosis factor antagonists in adults with psoriatic disease: a systematic review and meta-analysis of randomized controlled trials. J Am Acad Dermatol 201 I, 64: 1035-50.

27. Mariette X, Matucci-Cerinic M, Pavelka K, Taylor P, van Vollenhoven R, Heatley R, Walsh C, Lawson R, Reynolds A, Emery P: Malignancies associated with tumour necrosis factor inhibitors in registries and prospective observational studies: a systematic review and meta-analysis. Ann Rheum Dis 201 I, 70:1895-904.

\section{FlOOOPrime
RECOMMENDED}

28. Leonardi CL, Kimball AB, Papp KA, Yeilding N, Guzzo C, Wang Y, Li S, Dooley LT, Gordon KB: Efficacy and safety of ustekinumab, a human interleukin- I 2/23 monoclonal antibody, in patients with psoriasis: 76-week results from a randomised, double-blind, placebo-controlled trial (PHOENIX I). Lancet 2008, 37 I: 1665-74.

\section{FlOOOPrime
RECOMMENDED}

29. Gordon KB, Langley RG, Gottlieb AB, Papp KA, Krueger GG, Strober BE, Williams DA, Gu Y, Valdes JM: A phase III, randomized, controlled trial of the fully human IL- I 2/23 mAb briakinumab in moderate-to-severe psoriasis. Invest Dermatol 2012, 132:304-I4.

30. Gordon KB, Papp KA, Langley RG, Ho V, Kimball AB, Guzzo C, Yeilding N, Szapary PO, Fakharzadeh S, Li S, Hsu M, Reich K: Long-term safety experience of ustekinumab in patients with moderate to severe psoriasis (Part II of II): results from analyses of infections and malignancy from pooled phase II and III clinical trials. J Am Acad Dermatol 2012, 66:742-5I.

3I. McInnes IB, Kavanaugh A, Gottlieb AB, Puig L, Rahman P, Ritchlin C, Brodmerkel C, Li S, Wang Y, Mendelsohn AM, Doyle MK: Efficacy and safety of ustekinumab in patients with active psoriatic arthritis: I year results of the phase 3, multicentre, double-blind, placebo-controlled PSUMMIT I trial. Lancet 20I3, 382:780-9.

\section{FlOOOPrime}

\section{RECOMMENDED}

32. Lin AM, Rubin Cl, Khandpur R, Wang JY, Riblett M, Yalavarthi S, Villanueva EC, Shah P, Kaplan MJ, Bruce AT: Mast cells and neutrophils release IL-I 7 through extracellular trap formation in psoriasis. J Immunol 20I I, 187:490-500.

\section{FlOOOPrime
RECOMMENDED}

33. Leonardi C, Matheson R, Zachariae C, Cameron G, Li L, Edson-Heredia E, Braun D, Banerjee S: Anti-interleukin-17 monoclonal antibody ixekizumab in chronic plaque psoriasis. N Engl J Med 2012, 366: II $190-9$

\section{FlOOOPrime}

\section{RECOMMENDED}

34. Papp KA, Langley RG, Sigurgeirsson B, Abe M, Baker DR, Konno P, Haemmerle S, Thurston HJ, Papavassilis C, Richards HB: Efficacy and safety of secukinumab in the treatment of moderate-tosevere plaque psoriasis: a randomized, double-blind, placebocontrolled phase II dose-ranging study. Br J Dermatol 2013, I68: $4|2-2|$.

FlOOOPrime RECOMMENDED 
35. Papp KA, Leonardi C, Menter A, Ortonne J, Krueger JG, Kricorian G, Aras G, Li J, Russell CB, Thompson EHZ, Baumgartner S: Brodalumab, an anti-interleukin- I7-receptor antibody for psoriasis. $N$ Engl J Med 20I2, 366: II8I-9.

\section{FlOOOPrime \\ RECOMMENDED}

36. Sherlock JP, Joyce-Shaikh B, Turner SP, Chao C, Sathe M, Grein J, Gorman DM, Bowman EP, McClanahan TK, Yearley JH, Eberl G, Buckley CD, Kastelein RA, Pierce RH, Laface DM, Cua DJ: IL-23 induces spondyloarthropathy by acting on ROR- $\gamma t+C D 3+C D 4-$ CD8- entheseal resident T cells. Nat Med 20I2, 18:1069-76.

\section{FOOOPrime}

37. Lubberts E, Koenders MI, Oppers-Walgreen B, van den Bersselaar L, Coenen-de Roo CJJ, Joosten LAB, van den Berg WB: Treatment with a neutralizing anti-murine interleukin- 17 antibody after the onset of collagen-induced arthritis reduces joint inflammation, cartilage destruction, and bone erosion. Arthritis Rheum 2004, 50:650-9.

38. Genovese MC, Durez P, Richards HB, Supronik J, Dokoupilova E, Mazurov V, Aelion JA, Lee S, Codding CE, Kellner H, Ikawa T, Hugot S, Mpofu S: Efficacy and safety of secukinumab in patients with rheumatoid arthritis: a phase II, dose-finding, double-blind, randomised, placebo controlled study. Ann Rheum Dis 2013, 72: 863-9.

39. McInnes IB, Sieper J, Braun J, Emery P, van der Heijde D, Isaacs JD, Dahmen G, Wollenhaupt J, Schulze-Koops H, Kogan J, Ma S, Schumacher MM, Bertolino AP, Hueber W, Tak PP: Efficacy and safety of secukinumab, a fully human anti-interleukin-I7A monoclonal antibody, in patients with moderate-to-severe psoriatic arthritis: a 24-week, randomised, double-blind, placebo-controlled, phase II proof-of-concept trial. Ann Rheum Dis 2013, [Epub ahead of print].

40. Bovenschen HJ, Langewouters AMG, van de Kerkhof PCM: Dimethylfumarate for psoriasis: Pronounced effects on lesional T-cell subsets, epidermal proliferation and differentiation, but not on natural killer $T$ cells in immunohistochemical study. Am J Clin Dermatol 2010, I I:343-50.

4I. Kreuter A, Knierim C, Stücker M, Pawlak F, Rotterdam S, Altmeyer P, Gambichler T: Fumaric acid esters in necrobiosis lipoidica: results of a prospective noncontrolled study. Br J Dermatol 2005, 153:802-7.

42. Gold R, Kappos L, Arnold DL, Bar-Or A, Giovannoni G, Selmaj K, Tornatore C, Sweetser MT, Yang M, Sheikh SI, Dawson KT: Placebocontrolled phase 3 study of oral BG- 2 for relapsing multiple sclerosis. N Engl J Med 2012, 367:1098-107.

\section{FlOOOPrime \\ RECOMMENDED}

43. Fox RJ, Miller DH, Phillips JT, Hutchinson M, Havrdova E, Kita M, Yang M, Raghupathi K, Novas M, Sweetser MT, Viglietta V, Dawson KT: Placebo-controlled phase 3 study of oral BG- 12 or glatiramer in multiple sclerosis. N Engl J Med 20 I2, 367: 1087-97.

\section{FlOOOPrime} RECOMMENDED

44. Vandermeeren $M$, Janssens $S$, Wouters $H$, Borghmans I, Borgers $M$, Beyaert R, Geysen J: Dimethylfumarate is an inhibitor of cytokine-induced nuclear translocation of NF-kappa B I, but not RelA in normal human dermal fibroblast cells. J Invest Dermatol 200I, I 16: 124-30.

45. Peng $H$, Guerau-de-Arellano M, Mehta VB, Yang $Y$, Huss DJ, Papenfuss TL, Lovett-Racke AE, Racke MK: Dimethyl fumarate inhibits dendritic cell maturation via nuclear factor $\kappa B(N F-\kappa B)$ and extracellular signal-regulated kinase I and 2 (ERKI/2) and mitogen stress-activated kinase I (MSKI) signaling. J Biol Chem 2012, 287:28017-26.

46. The Lenercept Multiple Sclerosis Study Group and The University of British Columbia MS/MRI Analysis Group: TNF neutralization in
MS: results of a randomized, placebo-controlled multicenter study. Neurology 1999, 53:457-65.

47. Segal BM, Constantinescu CS, Raychaudhuri A, Kim L, Fidelus-Gort R, Kasper LH: Repeated subcutaneous injections of ILI 2/23 p40 neutralising antibody, ustekinumab, in patients with relapsingremitting multiple sclerosis: a phase II, double-blind, placebocontrolled, randomised, dose-ranging study. Lancet Neurol 2008, 7:796-804.

\section{FlOOOPrime
RECOMMENDED}

48. Schett G, Sloan VS, Stevens RM, Schafer P: Apremilast: a novel PDE4 inhibitor in the treatment of autoimmune and inflammatory diseases. Ther Adv Musculoskelet Dis 2010, 2:27I-8.

49. Papp K, Cather JC, Rosoph L, Sofen H, Langley RG, Matheson RT, Hu C, Day RM: Efficacy of apremilast in the treatment of moderate to severe psoriasis: a randomised controlled trial. Lancet 2012, 380:738-46.

\section{FlOOOPrime}

50. Schett G, Wollenhaupt J, Papp K, Joos R, Rodrigues JF, Vessey AR, Hu C, Stevens R, de Vlam KL: Oral apremilast in the treatment of active psoriatic arthritis: results of a multicenter, randomized, double-blind, placebo-controlled study. Arthritis Rheum 20I2, 64:3I56-67.

\section{FlOOOPrime
RECOMMENDED}

5I. Changelian PS, Flanagan ME, Ball DJ, Kent CR, Magnuson KS, Martin WH, Rizzuti BJ, Sawyer PS, Perry BD, Brissette WH, McCurdy SP, Kudlacz EM, Conklyn MJ, Elliott EA, Koslov ER, Fisher MB, Strelevitz TJ, Yoon K, Whipple DA, Sun J, Munchhof MJ, Doty JL, Casavant JM, Blumenkopf TA, Hines M, Brown MF, Lillie BM, Subramanyam C, Shang-Poa C, Milici AJ, et al.: Prevention of organ allograft rejection by a specific Janus kinase 3 inhibitor. Science 2003, 302:875-8.

\section{FlOOOPrime
RECOMMENDED}

52. Ghoreschi K, Laurence A, O'Shea J]: Janus kinases in immune cell signaling. Immunol Rev 2009, 228:273-87.

53. Fridman IS, Scherle PA, Collins R, Burn TC, Li Y, Li J, Covington MB, Thomas B, Collier P, Favata MF, Wen X, Shi J, McGee R, Haley PJ, Shepard S, Rodgers JD, Yeleswaram S, Hollis G, Newton RC, Metcalf B, Friedman SM, Vaddi K: Selective inhibition of JAKI and JAK2 is efficacious in rodent models of arthritis: preclinical characterization of INCB028050. J Immunol 2010, 184:5298-307.

54. Ghoreschi K, Jesson MI, Li X, Lee JL, Ghosh S, Alsup JW, Warner JD, Tanaka M, Steward-Tharp SM, Gadina M, Thomas C], Minnerly JC, Storer CE, LaBranche TP, Radi ZA, Dowty ME, Head RD, Meyer DM, Kishore N, O'Shea J]: Modulation of innate and adaptive immune responses by tofacitinib (CP-690,550). I Immunol 20II, 186: 4234-43.

55. Ghoreschi K, Gadina M: JAKpot! New small molecules in autoimmune and inflammatory diseases. Exp Dermatol 2013, [Epub ahead of print].

56. Papp KA, Menter A, Strober B, Langley RG, Buonanno M, Wolk R, Gupta P, Krishnaswami S, Tan H, Harness JA: Efficacy and safety of tofacitinib, an oral Janus kinase inhibitor, in the treatment of psoriasis: a Phase $2 \mathrm{~b}$ randomized placebo-controlled doseranging study. $\mathrm{Br} J$ Dermatol 2012, 167:668-77.

\section{FlOOOPrime \\ RECOMMENDED}

57. Ports WC, Khan S, Lan S, Lamba M, Bolduc C, Bissonnette R, Papp K: A randomized phase $2 a$ efficacy and safety trial of the topical Janus kinase inhibitor tofacitinib in the treatment of chronic plaque psoriasis. Br J Dermatol 2013, 169:137-45.

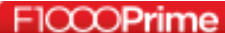


58. Fleischmann R, Kremer J, Cush J, Schulze-Koops H, Connell CA, Bradley JD, Gruben D, Wallenstein GV, Zwillich SH, Kanik KS: Placebo-controlled trial of tofacitinib monotherapy in rheumatoid arthritis. N Engl J Med 20I2, 367:495-507.

\section{FlOOOPrime

RECOMMENDED

59. van Vollenhoven RF, Fleischmann R, Cohen S, Lee EB, García Meijide JA, Wagner S, Forejtova S, Zwillich SH, Gruben D, Koncz T, Wallenstein GV, Krishnaswami S, Bradley JD, Wilkinson B: Tofacitinib or adalimumab versus placebo in rheumatoid arthritis. N Engl J Med 20I2, 367:508-19.

\section{FlOOOPrime}

\section{RECOMMENDED}

60. Sandborn WJ, Gasink C, Gao L, Blank MA, Johanns J, Guzzo C, Sands BE, Hanauer SB, Targan S, Rutgeerts P, Ghosh S, de Villiers WJS, Panaccione R, Greenberg G, Schreiber S, Lichtiger S, Feagan BG: Ustekinumab induction and maintenance therapy in refractory Crohn's disease. $N$ Engl J Med 2012, 367:1519-28.

6I. Braumüller H, Wieder T, Brenner E, Aßmann S, Hahn M, Alkhaled M, Schilbach K, Essmann F, Kneilling M, Griessinger C, Ranta F, Ullrich S, Mocikat R, Braungart K, Mehra T, Fehrenbacher B, Berdel J,
Niessner H, Meier F, van den Broek M, Häring H, Handgretinger R, Quintanilla-Martinez L, Fend F, Pesic M, Bauer J, Zender L, Schaller M, Schulze-Osthoff K, Röcken M: T-helper-I-cell cytokines drive cancer into senescence. Nature 2013, 494:36I-5.

\section{FlOOOPRime
RECOMMENDED}

62. Zheng $Y$, Danilenko DM, Valdez P, Kasman I, Eastham-Anderson J, Wu J, Ouyang W: Interleukin-22, a $\mathbf{T}(\mathbf{H})$ I7 cytokine, mediates IL-23-induced dermal inflammation and acanthosis. Nature 2007, 445:648-5I.

\section{FlOOOPrime} RECOMMENDED

63. Hirahara K, Ghoreschi K, Yang X, Takahashi H, Laurence A, Vahedi G, Sciumè G, Hall AO, Dupont CD, Francisco LM, Chen Q, Tanaka M, Kanno Y, Sun H, Sharpe AH, Hunter CA, O'Shea J]: Interleukin-27 priming of $\mathbf{T}$ cells controls IL-I7 production in trans via induction of the ligand PD-LI. Immunity 2012, 36:1017-30.

64. Ghoreschi K, Laurence A, O'Shea JJ: Selectivity and therapeutic inhibition of kinases: to be or not to be? Nat Immunol 2009, 10:356-60. 